\title{
肉芽腫性エプーリスの一例
}

\section{A case of Epulis Granulomatosa}

\author{
総合病院山口赤十字病院歯科（医長：宇都宮和喜）

\section{宇都宮 和 喜 - 小川善 之・宇都宮 鈴 代}

\section{緒言}

エプーリスは、菡科臨床上かなりしばしば遭遇する 重要な疾患で、比較的発生頻度の高い炎症性エプーリ スをはじめとして、腫瘍性エプーリス、まれれ出現す る巨細胞性エプーリスとに区別される。われわれは、 最近、下顎左側側切蒌舌側涵肉堂基瓦とした巨大な肉 考腫性エプーリスて摘出する機会を得たので、茲に報 告し、諸賢の報告に追加する次第である。

\section{症}

\section{例}
患 者: 永 $\bigcirc$ 利 $\bigcirc 26$ 才
初診：炤和38年7月.9日
主 訴：食摂不能
家 族 歴：特記すべき事項なし

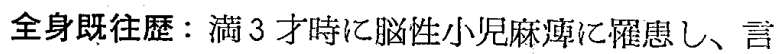
語障碍、歩行不能である。

現症既往歴：昭和33年頃、下顎左側側切潧舌側菡肉 に、小豆大の出血性溃湯壳認めたが放置していたとて ろ、漸次增大し、昭和38年 8 月頃汃污、閉口障碍、食 物摂取障碍を訴えるようになつたので本院外科に受 䛦、㧘科にまわされた。

現、症：患者は全身的に発育不全、栄養状態不 良、両下肢は運動麻痺のため起立ならびに歩行は不能 である。赤血球数 244 万、白血球数 4,400 、血色素 $42 \%$ 出血時間 3 分 30 秒、凝固時間開始 3 分 5 秒、完結 9 分 45秒で略々正常であり、ワ氏反応、村田氏反応はとも に陰性であった。

顔貌所見：病相总呈し、顔色篬白、眼臉結膜は貧血 性で、口腔前庭より上下口唇の間には赤褐色で、出血 性凸四不平の潰瘍をともなつた大鵎卵大の腫瘤があり その1部は口腔外に溢出し、そのために閉口不能であ

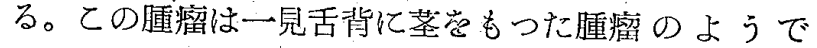
あった。顔下には大豆大に腫脹したリンパ節 2 ケをふ れるが、右顎下リンパ節の尰脹は認められなかつた。

口腔内所見：口腔内は不橴で、㐘牙は上顎左右側第 2 大鼠丵守存在していたが、76|67は第3度の

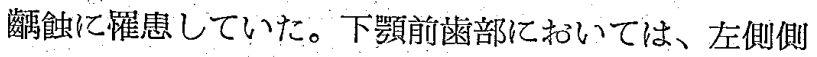

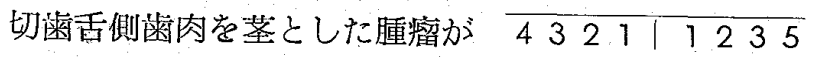

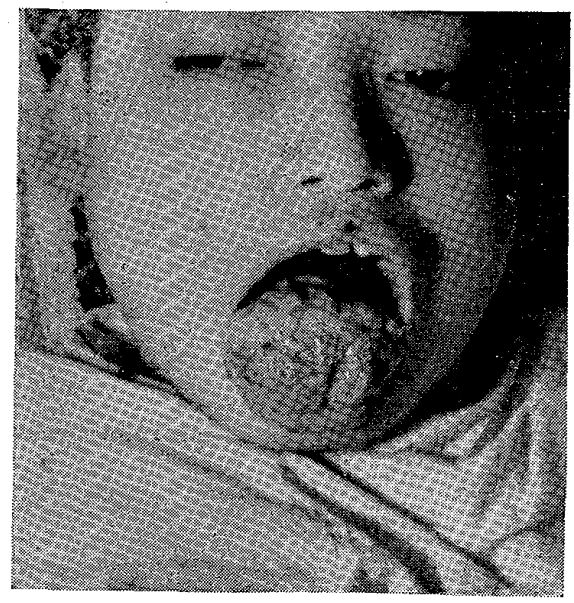

にわたる歯列を包み、歯慒をこえて唇側歯肉党も完全

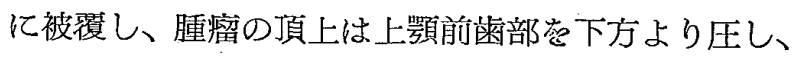
強度の唇側傾科总来たしている。口腔前庭は、腫瘤で 充满され、歯慒頂甞越えて口腔外に湓出しているため 常時、開口状態である。腫溜の大きさは鵎卵大、褐赤

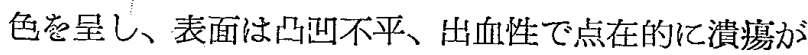
みられ、広い茎葛もつて、舌側崡肉と連結している。 硬度は弾力性硬で压痛は軽度であった。

X.R 所見：下顎左側側切歯党中心䎲し、下顎左側 大崡、下顎左側第一小曰崡骀強く遠心傾斜し、同部の 函槽骨吸収は著じるしい。下顎左側中切菡は近心傾斜 
し、同部の崡槽骨吸収もみられる。下顎右側中切崡、

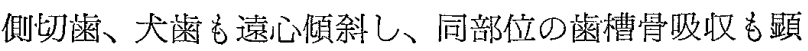
著である。

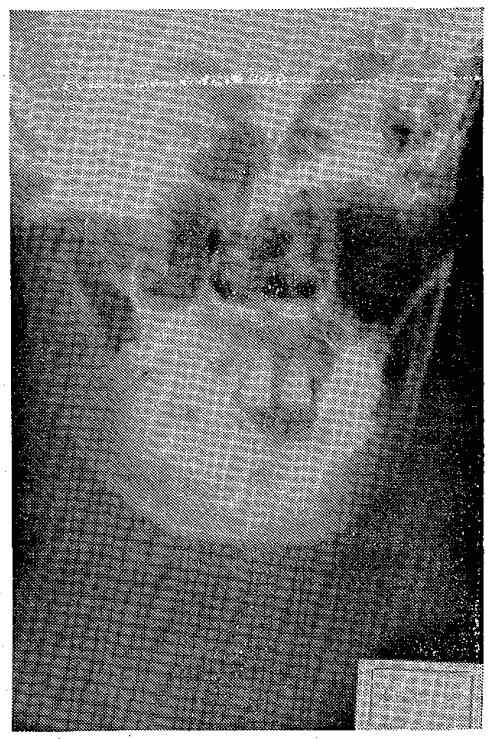

臨床診断：下顎崡槽部の歯肉腫。

処置および経過：大院の上、雄血的に董湯摘出し た。321/1234 亿わたる蒾槽骨は、著明な吸 収索示し、 $\overline{21 \mid 12}$ は腫瘍内に埋入されてをり、 了|34 動摇著明だつたため、保存不可能と考えた ので抜去した。同時に、同部位の菡槽骨旁可及的に㢣 除した。術中出血 $250 \mathrm{cc}$ 、術後 2 日間に計 $400 \mathrm{cc}$ の輸 血堂行なった。一方術後当日から、マイシリン $1 \mathrm{~g}$ の 筋肉注射觉10日間続行し、入院11日で軽快退院した。

摘出物内眼的所見：腫綮は笑質性で褐赤色裳呈し、 表面は山凸不平、部分的に潰瘍がみられた。大きさは $5 \mathrm{~cm} \times 5 \mathrm{~cm} \times 3 \mathrm{~cm}$ であつた。

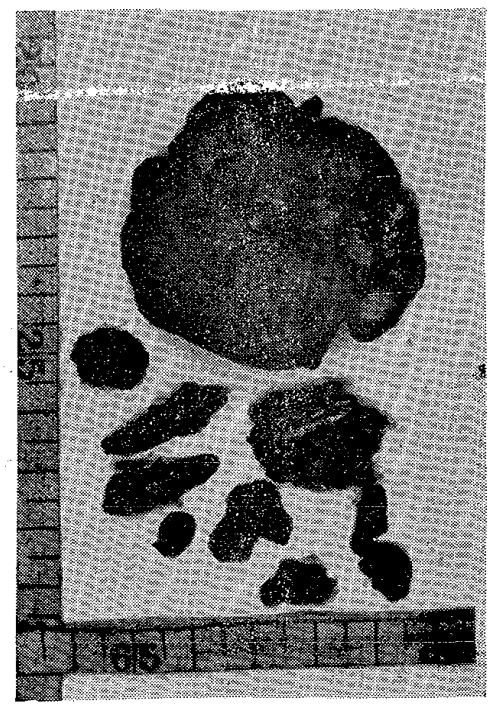

病理組織学的所見：最外凰には角化总伴なつた上皮層
がみられるが、部分的には上皮層壱欠くところもみら れる。上皮下は全般的に、比較的血管に富む肉转組織 から成り、特に血管周团には円形細胞の浸潤が著し い。深部にいたつても肉第組織の状驡にもかわりはな いが、一部には線維性変化党示し、いわ線維性土 プーリスに近い組織像裳する部分も混在している。

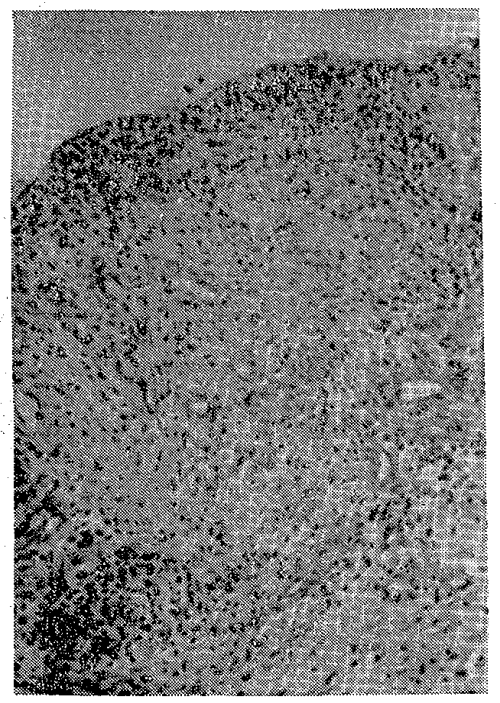

考按

歯肉に生じたすべての腫愓をエプーリスという言葉 で古くから呼んで来たが、現在では、歯槽突起に生じ た炎症性新生物和よび線維厙ないしてれに類する腫瘍 甞総括した臨床的な名称で呼ぶならわしである。臨床 的㑊肉上より有萃的に発育した新生物で、一般 に緩慢な経過堂迻り、概して良性のものとされている が、時に再発管みるととがある。好発部位は、上顎前 霜部に最も多く、上下顎大曰蒾部、下顎前歯部和よび 小曰菡部、上顎小曰蒾部之いわれている。歯槽突起の 外側记発育するてとが多く、次いで潇慒堤上であり、 円側て生じるととは比較的少密い。年令的には、20才 〜 40表に多く出現し、Bernierによれば、平垥発生年 令 32.1 才である。市た比較的女性化多く現われ、 Grüner（1915）の観察では、女性対男生の比结2.2対 1であつた。特に娃娠時に色速に增大ずるてとがあ

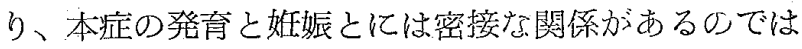
ないかといわれている。組織学的には、炎症性エプー リス、腫眗性エプーリス、巨細肘性エプーリスの3種 に分類している人が多い。報告者によってはさらにて れ总細分し、肉芽腫性、線維腫性、血管拡張性、血管 腫性エプーリス和よび線維腫性、骨線維腫性エプーリ 又等之分類報告している。一方巨細胞性エプーリスに ついては、巨細胞の由来に関し、諸学者の間で種々論 
議され、本症汃炎症性新生物汃、真性董瘍汃の中心点 となつている。すなわち、Bardelben-Vidal (1860) によつて、線維腫性エプーリスと肉腫性エプーリスに 分けられて、人しく真性の腫晹とみなされていたが、 Ritter (1900)、Lubarsch (1907) 等は、炎症性新生 物であるとの見解莨出し、 Siegmund 㐨よび Weber (1926) によつて、ェプーリスは、全て炎症性腫瘍状 新生物であるとのへられた。これれ反し、Albertini

（1928）は、肉腫ではないが、炎症性のものではなく 間葉性の真性の腫瘦であると主張した。Borschers (1932)、Lindemann (1928) も腫瘍説歘のべてい る。都築 (1932) は、エプーリスに惔症性のものと 腫瘍性のものとがあるとのべ、正木（1938） は、崡固 組織の結合組織起母地とした腫瘍状の炎症性新生物で あるとしている。宮崎 (1942) は、Albertini 等と同 一の見解薂もち、肉腫ではなく、炎症性のものでもな く、いわゆる良性巨細胞性腫癔とすべきであるとのべ ている。渡辺（1948）も同様に、巨細胞性エプーリス のみ良性巨細胞性腫序と考えるべきで、その他のエプ ーリスは、炎症性新生物とず゙きであるとの見解を とつている。

現在では、病理組織学的にエプーリス忞分類し、

1）炎症性エプーリス、肉第腫性エプーリス、線維 性エプーリス等
2）腫瘍性エプーリス、線維腫性エプーリス、骨線 維腫性エプーリス

3）巨細胞性エプーリス

に分類さ元ている。

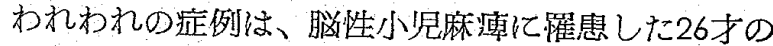
発育不全の男子の下枵左側側切歯吉側歯因学母地とし て発生した巨大な、肉先腫性ェプーリスであって、炎 症性新生物と考えられるものであった。

\section{結 語}

本症例は、脳性小光麻算に罹患した、26才の発育不 全の男子の、下顎左側側切米舌側雪肉基底として、 5 年閻で約大舀卵大に発育した、肉伢腫性エプーリス であつた。

稿堂終わるに当り、御指導御教示賜わつた、中央 検查室の吉永博士に深謝致します。

\section{参考 文 献}

1）吉光他：巨細胞性エプーリスの1例、広島医学 7 (9)

2）窝崎他：口腔病理学後編、永末書店、昭和33年

3）藤田他：巨細胞性エプーリスの1例、日本口腔 科学会雑誌、4 巻、1955

4）大并清：口腔外科学、永未書店、昭和32年 